\author{
DEPARTMENT OF THE INTERIOR \\ UNITED STATES GEOLOGICAL SURVEY
}

\title{
MAP SHOWING INFERRED RELATIVE PERMEABILITY OF GEOLOGIC MATERIALS IN THE PARKER QUADRANGLE, ARAPAHOE AND DOUGLAS COUNTIES, COLORADO

$$
\text { By }
$$

John O. Maberry

\author{
FOLIO OF THE \\ PARKER QUADRANGLE, COLORADO \\ MAP I-770-I
}

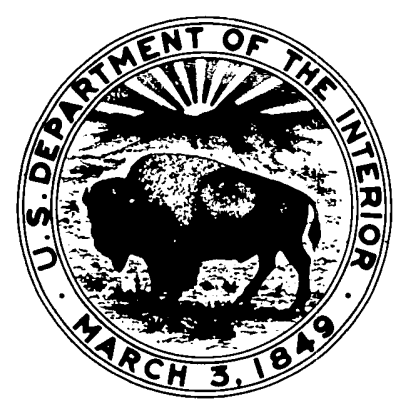

PUBLISHED BY THE U.S. GEOLOGICAL SURVEY 